\title{
Dopamine D2 Receptor Signaling in the Nucleus Accumbens Comprises a Metabolic-Cognitive Brain Interface Regulating Metabolic Components of Glucose Reinforcement
}

\author{
Michael Michaelides*,1,2,3,4,6, Michael L Miller ${ }^{1,2}$, Jennifer A DiNieri',2, Juan L Gomez ${ }^{3}$, Elizabeth Schwartz', \\ Gabor Egervari ${ }^{1,2}$, Gene Jack Wang ${ }^{5}$, Charles V Mobbs', Nora D Volkow ${ }^{5}$ and Yasmin L Hurd ${ }^{1,2}$ \\ 'Fishberg Department of Neuroscience, Icahn School of Medicine at Mount Sinai, New York, NY, USA; ${ }^{2}$ Department of Psychiatry, Friedman Brain \\ Institute, Icahn School of Medicine at Mount Sinai, New York, NY, USA; ${ }^{3}$ Biobehavioral Imaging and Molecular Neuropsychopharmacology Unit, \\ National Institute on Drug Abuse Intramural Research Program, Baltimore, MD, USA; ${ }^{2}$ Department of Psychiatry, Johns Hopkins School of \\ Medicine, Baltimore, MD, USA; ${ }^{5}$ Laboratory of Neuroimaging, National Institute on Alcohol Abuse and Alcoholism, National Institutes of Health, \\ Bethesda, MD, USA
}

\begin{abstract}
Appetitive drive is influenced by coordinated interactions between brain circuits that regulate reinforcement and homeostatic signals that control metabolism. Glucose modulates striatal dopamine (DA) and regulates appetitive drive and reinforcement learning. Striatal DA D2 receptors (D2Rs) also regulate reinforcement learning and are implicated in glucose-related metabolic disorders. Nevertheless, interactions between striatal D2R and peripheral glucose have not been previously described. Here we show that manipulations involving striatal D2R signaling coincide with perseverative and impulsive-like responding for sucrose, a disaccharide consisting of fructose and glucose. Fructose conveys orosensory (ie, taste) reinforcement but does not convey metabolic (ie, nutrient-derived) reinforcement. Glucose however conveys orosensory reinforcement but unlike fructose, it is a major metabolic energy source, underlies sustained reinforcement, and activates striatal circuitry. We found that mice with deletion of dopamine- and cAMP-regulated neuronal phosphoprotein (DARPP-32) exclusively in D2R-expressing cells exhibited preferential D2R changes in the nucleus accumbens (NAc), a striatal region that critically regulates sucrose reinforcement. These changes coincided with perseverative and impulsive-like responding for sucrose pellets and sustained reinforcement learning of glucose-paired flavors. These mice were also characterized by significant glucose intolerance (ie, impaired glucose utilization). Systemic glucose administration significantly attenuated sucrose operant responding and D2R activation or blockade in the NAc bidirectionally modulated blood glucose levels and glucose tolerance. Collectively, these results implicate NAc D2R in regulating both peripheral glucose levels and glucose-dependent reinforcement learning behaviors and highlight the notion that glucose metabolic impairments arising from disrupted NAc D2R signaling are involved in compulsive and perseverative feeding behaviors. Neuropsychopharmacology (2017) 42, 2365-2376; doi:I0.I038/npp.2017.I I2; published online 19 July 2017
\end{abstract}

\section{INTRODUCTION}

In the United States, sucrose (ie, dietary sugar) is markedly consumed in excess of metabolic need, with the average individual eating $\sim 4$ times the recommended amount (Johnson et al, 2009). This sucrose overconsumption is associated with a variety of metabolic abnormalities, adverse health issues (Johnson et al, 2009), and induction of addictivelike behaviors that, in certain cases, can be comparable to those induced by drugs of abuse (Ahmed et al, 2013).

\footnotetext{
*Correspondence: Dr M Michaelides, Biobehavioral Imaging and Molecular Neuropsychopharmacology Unit, National Institute on Drug Abuse Intramural Research Program, 25 I Bayview Boulevard, Baltimore, MD 21224, USA. Tel: +I 443740 2894, Fax: + I 443740 2122, E-mail: mike.michaelides@nih.gov

${ }^{6}$ Current address: Biobehavioral Imaging and Molecular Neuropsychopharmacology Unit, National Institute on Drug Abuse Intramural Research Program, Baltimore, MD 21224, USA

Received 6 January 20 17; revised 17 May 2017; accepted 19 May 20 17; accepted article preview online 5 June 2017
}

Sucrose is a disaccharide comprising fructose and glucose molecules in a $1: 1$ ratio. Although glucose and fructose both convey orosensory (ie, taste) reinforcement, only glucose can convey metabolic (ie, nutrient-derived) reinforcement (Sclafani et al, 1993). Being that food reward is primarily driven by metabolic and less so by orosensory reinforcement (de Araujo, 2011), it is not surprising that laboratory animals readily prefer glucose over fructose (Sclafani and Ackroff, 2012) and that metabolic reinforcement, as opposed to taste, critically regulates long-term reinforcement learning and reward (Beeler et al, 2012; de Araujo, 2011).

Peripheral glucose is known to modulate reward/reinforcement learning systems (Bello and Hajnal, 2006; Delaere et al, 2013), reward learning (Ackroff et al, 2010), and striatal dopamine (DA) release (Oliveira-Maia et al, 2011). Involvement of glucose as a metabolic reinforcer is also observed in humans, where glucose consumption activates DA-rich striatal regions (that are associated with reward) (Page et al, 2013) and this type of glucose-mediated striatal 
activation correlates with blood glucose levels (de Araujo et al, 2013). Importantly, foods with high glycemic loads (ie, high propensity to raise an individual's blood glucose level upon consumption) preferentially activate striatal reward regions implicated in addiction (Lennerz et al, 2013) and food-related addictive behaviors are primarily associated with these types of foods (Schulte et al, 2015).

Striatal DA D2 receptors (D2Rs) regulate approach/ avoidance and reinforcement learning and are implicated in both drug and food-related addictive behaviors and metabolic disorders (Kenny et al, 2013; Kravitz and Kreitzer, 2012; Lobo and Nestler, 2011; Yawata et al, 2012). Importantly, pharmacological activation or overexpression of striatal D2R increases motivation, perseverative feeding, as well as impulsivity (Haluk and Floresco, 2009; Horvitz et al, 2001; Moreno et al, 2013; Trifilieff et al, 2013) and systemic administration of D2R agonists alters blood glucose levels (Scranton and Cincotta, 2010). Nevertheless, the specific involvement of striatal $\mathrm{D} 2 \mathrm{R}$ in modulating glucose-derived reinforcement and/or peripheral glucose metabolism has not been investigated.

Dopamine- and cAMP-regulated phosphoprotein of $32 \mathrm{kDa}$ (DARPP-32) is a signaling phosphoprotein that is expressed predominantly in striatum, and therein specifically in medium spiny neurons (MSNs). Notably, DARPP-32 activity is decreased upon D2R activation (Lindskog et al, 1999). DARPP-32 directly modulates physiological and behavioral responses to DA (Fienberg et al, 1998) and plays a critical role in DA-mediated drug (Borgkvist and Fisone, 2006) and sucrose reinforcement (particularly in the shell of the nucleus accumbens (NAc)) (Scheggi et al, 2013). However, its role and that of D2R signaling in the behavioral and metabolic components of sucrose and glucose reinforcement are not well understood. Mice with conditional DARPP-32 deletion from D2R MSNs exhibit increased locomotor activity and impaired corticostriatal long-term potentiation (LTP) (Bateup et al, 2010), effects that are recapitulated by $\mathrm{D} 2 \mathrm{R}$ agonists (Centonze et al, 2001; Haluk and Floresco, 2009; Horvitz et al, 2001; Lindskog et al, 1999; Nishi et al, 1997) that, as noted previously, inhibit DARPP-32 (Lindskog et al, 1999). Therefore, DARPP-32 deletion from D2R MSNs would be expected to elicit similar changes as increased DA activity at D2R. Here we tested these mice in concert with pharmacological approaches to demonstrate that striatal D2R signaling modulates operant responding and impulsive choice behavior for sucrose, as well as peripheral glucose levels and glucosederived reward and reinforcement learning.

\section{MATERIALS AND METHODS}

\begin{abstract}
Animals
We used adult male C57/Bl6 mice and adult male conditional knockout mice with dopamine- and cAMP-regulated phosphoprotein of $32 \mathrm{kDa}$ (DARPP-32; D32) deletion in Drd2expressing cells (ie, floxed D32 were crossed with Drd2-cre expressing mice (ER44 line) as previously described; Bateup et al, 2010). All animals were maintained under standard laboratory conditions with ad libitum access to normal chow and water except where noted. All procedures were conducted during the animals' active cycle and were in agreement with the National Academy of Sciences Guide for
\end{abstract}

the Care and Use of Laboratory Animals and institutional animal care and use committee protocols.

\section{Tissue Harvesting and Preparation}

Animals were killed as per institutional protocols. The brain was rapidly removed and frozen in an isopentane and dry ice bath and stored in a $-80^{\circ} \mathrm{C}$ freezer.

\section{Quantitative Real-Time PCR (qPCR)}

Frozen brains were sectioned $(20 \mu \mathrm{m})$ at the striatum using a cryostat (Microm HM560, Thermo Scientific, Rockford, IL) and a dissecting microscope and sterile scalpels were used to dissect out the caudate putamen $(\mathrm{CPu})$ and NAc. Slides were kept on dry ice throughout the procedure. Total RNA was isolated with the RNAGEM Tissue Plus extraction kit (ZyGEM, Hamilton, New Zealand). After RNA extraction, PCR was performed to synthesize cDNA using qScript cDNA Supermix reagent (Quanta BioSciences, Gaithersburg, MD). A TaqMan gene expression assay (Applied Biosystems, Carlsbad, CA) was used to quantify mRNA expression for Drd2. All reactions were performed in triplicate. The $d d \mathrm{C}_{t}$ method was used to determine relative mRNA expression that was expressed relative to $18 \mathrm{~S}$ rRNA.

\section{$\left[{ }^{35} \mathrm{~S}\right] \mathrm{GTP} \gamma \mathrm{S}$ Autoradiography}

$\left[{ }^{35} \mathrm{~S}\right] \mathrm{GTP} \gamma \mathrm{S}$ autoradiography was assessed using previously published protocols (Laitinen and Jokinen, 1998). Briefly, slides with $20 \mu \mathrm{m}$-thick cut sections were incubated in preincubation buffer ( $50 \mathrm{mM}$ Tris-HC1 (pH 7.4), $1 \mathrm{mM}$ EDTA, $100 \mathrm{mM} \mathrm{NaCl}$, and $5 \mathrm{mM} \mathrm{MgC1}_{2}$ ) for $20 \mathrm{~min}$ at $20^{\circ} \mathrm{C}$ (0.6 ml per slide). Slides were then incubated for $1 \mathrm{~h}$ at $20^{\circ} \mathrm{C}$ in the above buffer with the addition of $2 \mathrm{mM}$ guanosine diphosphate (GDP) and $1 \mu \mathrm{M}$ dipropylxanthine (DPCPX). Finally, slides were incubated in preincubation buffer also containing $80-100 \mathrm{pM}\left[{ }^{35} \mathrm{~S}\right] \mathrm{GTP} \gamma \mathrm{S}, 2 \mathrm{mM}$ GDP, $1 \mathrm{mM}$ dithiothreitol, and $1 \mu \mathrm{M}$ DPCPX in combination with either excess buffer or the D2R agonist quinpirole $(1 \mu \mathrm{M})$ for $90 \mathrm{~min}$ at $20^{\circ} \mathrm{C}$. Nonspecific binding was assessed using $10 \mu \mathrm{M}$ GTP $\gamma \mathrm{S}$. The incubation cocktail was removed by aspiration, and sections were washed twice at $0{ }^{\circ} \mathrm{C}$ for $5 \mathrm{~min}$ each time in washing buffer $(50 \mathrm{mM}$ Tris- $\mathrm{HCl}$ and $5 \mathrm{mM}$ $\mathrm{MgCl}_{2}, \mathrm{pH}$ 7.4), rinsed in Millipore water for $30 \mathrm{~s}$, air-dried, and apposed to BAS-SR 2040 (GE Healthcare, Piscataway, NJ) phosphor imaging plates for 3 days. Imaging plates were developed using an FLA-7000 phosphorimager (GE Healthcare). Using Multigauge software (GE Healthcare), regions of interest (ROIs) were drawn on $\mathrm{CPu}$ and NAc shell and core of each section. Values were averaged and expressed as dpm/ $\mathrm{mg}$ with the use of $\left[{ }^{14} \mathrm{C}\right]$ standards.

\section{Sucrose Pellet Self-Administration}

At the beginning of each $1 \mathrm{~h}$ session, mice (D32 fl/fl $/ \mathrm{D} 2 \mathrm{cre}^{+}$ $(n=12)$ and $\left.\mathrm{D} 32^{\mathrm{fl} / \mathrm{fl}} / \mathrm{D} 2 \mathrm{cre}^{-}(n=8)\right)$ were placed into an illuminated operant chamber (house light on) with two levers in the extended position. A response on the active lever (fixed ratio 1 (FR1)) resulted in the delivery of one sucrose pellet, whereas a response on the inactive lever had no programmed consequence. A response on the active lever was followed by a 
$10 \mathrm{~s}$ timeout period during which a stimulus light above the active lever was illuminated and both levers were retracted. After the $10 \mathrm{~s}$ timeout period, a new trial was initiated. Behavioral activity was recorded during each session via an infrared beam monitoring system part of the operant chamber. For sucrose self-administration experiments in C57/Bl6 mice, mice were first trained for stable responses on an FR1 schedule. Mice were then exposed to 150 min sessions that began at $3 \mathrm{~h}$ into their dark cycle and coincided with IP pretreatment with vehicle or bromocriptine $(10 \mathrm{mg} / \mathrm{kg})$ and 15 min later followed by IP injections of vehicle or glucose $(2 \mathrm{~g} / \mathrm{kg})$ and then immediately proceeding with operant testing. Mice were exposed to the following four sessions: vehicle/vehicle, vehicle/glucose, vehicle/vehicle, and vehicle/ bromocriptine on four consecutive days.

\section{Intolerance to Delay Task (ITD)}

Mice $\left(\mathrm{D} 32^{\mathrm{fl} / \mathrm{fl}} / \mathrm{D} 2 \mathrm{cre}^{+}(n=12)\right.$ and $\left.\mathrm{D} 32^{\mathrm{fl} / \mathrm{fl}} / \mathrm{D} 2 \mathrm{cre}^{-}(n=14)\right)$ tested in the ITD task were required to lever press for sucrose pellets. Animals were food restricted (3-5g per day) and maintained at $\sim 85-90 \%$ of their free-feeding weights. Food restriction was initiated 3 days before behavioral testing and lasted throughout the experiment. ITD experiments were divided into three stages: pretraining, training, and testing. During pretraining, a response on one lever (active lever) resulted in the delivery of one pellet (FR1), whereas a response on the other lever (inactive lever) had no programmed consequence. Ten pretraining sessions were performed. The assignment of levers to the active or inactive condition was alternated on each session to avoid biasing the mice to one lever over the other. Successful completion of the pretraining stage was defined as total lever pressing of $\geqslant 20$ on the last two sessions. During the ITD training, animals learned to differentiate between the two levers based on reward magnitude. A response on the L1 lever resulted in the delivery of one sucrose pellet, whereas a response on the L5 lever resulted in the delivery of five pellets. After pellet delivery, a light inside the food magazine was illuminated for $25 \mathrm{~s}$, during which time additional L1 and L5 lever presses were recorded, but no additional pellet was delivered. At the end of the $25 \mathrm{~s}$ timeout period, animals were presented with a new choice trial. Animals had the opportunity to complete 60 choice trials during each daily 30 min training session. Training sessions were conducted until mice completed 20 choice trials and $60 \%$ of responding during choice trails was on the L5 lever. Data collected during ITD training were used to produce the delay $=0 \mathrm{~s}$ time point in ITD figures. After ITD training criteria were met, animals entered the testing stage of the experiment. ITD test sessions were the same as training sessions except that a delay was inserted between L5 lever pressing and pellet delivery. The delay was held constant within a session, and increased over subsequent sessions according to the following progression (in s): $10,20,40,60,80,100,120$, and 140 . During the delay, a house light was illuminated and lever pressing was recorded, but no additional pellets were delivered.

\section{Conditioned Flavor Preference Paradigm}

Mice $\left(\mathrm{D} 32^{\mathrm{fl} / \mathrm{fl}} / \mathrm{D} 2 \mathrm{cre}^{+}(n=9)\right.$ and $\left.\mathrm{D} 32^{\mathrm{fl} / \mathrm{fl}} / \mathrm{D} 2 \mathrm{cre}^{-}(n=9)\right)$ were fasted overnight and the next day (pretest $(\mathrm{PT})$ ) were given free access to two bottles, each containing either grapeflavored fructose (8\%) or cherry-flavored fructose (8\%) solutions for $30 \mathrm{~min}$ and intake was measured. Solutions were made by dissolving $80 \mathrm{~g}$ of fructose with $0.5 \mathrm{~g}$ of either KoolAid flavor in 1-liter of autoclaved water. The location of the bottles in the home cage was randomized to control for side preference. On the evening of PT, mice were given overnight access to either grape-flavored glucose $(8 \%)$ or cherry-paired fructose $(8 \%)$ (conditioning day 1 (CD1)) and intake was measured the next morning. Glucose solution was made as described above for fructose. The next evening, this was repeated (conditioning day 2 (CD2)) and bottles were switched between $\mathrm{CD} 1$ and $\mathrm{CD} 2$ sessions to control for side preference. Mice were then fasted overnight the following day and on the following morning TD1 (test day 1) was performed. Procedures and solutions were identical to PT. On the same day as TD1, in the evening, mice were given bottles containing the above flavor-nutrient pairings but this time the pairings were switched (grape-flavored fructose, cherry-flavored glucose) (reversal conditioning day 1 (RV1)). RV2 (reversal conditioning day 2) followed on the next day with identical procedures as CD2 (but with switched flavor pairings. Finally, the next evening, mice were fasted overnight and in the morning were exposed to the TD2 (test day 2) session whose procedures were identical to PT and TD1.

\section{Intraperitoneal Glucose Tolerance Tests (IPGTT) in Mice}

Glucose tolerance refers to the ability of an individual to clear glucose levels from the blood following glucose administration. Glucose intolerance is the opposite and reflects an inability or delay in clearance of elevated blood glucose. $\mathrm{D} 32^{\mathrm{fl} / \mathrm{fl}} / \mathrm{D} 2 \mathrm{cre}^{+}$and $\mathrm{D} 32^{\mathrm{fl} / \mathrm{fl}} / \mathrm{D} 2 \mathrm{cre}^{-}$mice and C57/Bl6 mice $(n=7)$ were fasted for $8 \mathrm{~h}$. At $\sim 3 \mathrm{~h}$ into their dark cycle, vehicle $\left(\mathrm{D} 32^{\mathrm{fl} / \mathrm{fl}} / \mathrm{D} 2 \mathrm{cre}^{+} \quad(n=6) ; \mathrm{D} 32^{\mathrm{fl} / \mathrm{fl}} / \mathrm{D} 2 \mathrm{cre}^{-} \quad(n=3)\right)$ or bromocriptine $(10 \mathrm{mg} / \mathrm{kg}) \quad\left(\mathrm{D} 32^{\mathrm{fl} / \mathrm{fl}} / \mathrm{D} 2 \mathrm{cre}^{+} \quad(n=6)\right.$; $\left.\mathrm{D} 32^{\mathrm{fl} / \mathrm{fl}} / \mathrm{D} 2 \mathrm{cre}^{-}(n=4)\right)$ was injected IP and then 15 min later glucose, dissolved in sterile water to generate a dose of $2 \mathrm{~g} / \mathrm{kg}$, was also injected IP and glucose measurements $(\mathrm{mg} / \mathrm{dl}$ in blood) were obtained at $0,30,60$, and 120 min after injection using a commercial glucometer. For IPGTT experiments after intracranial injections, male adult $\mathrm{C} 57 / \mathrm{Bl} 6$ mice $(n=7)$ were fitted with bilateral cannulas targeting the NAc shell (AP: 1.3, ML: $\pm 0.5, \mathrm{DV}:-4.0 \mathrm{~mm}$ ). After 1 week, mice were fasted for $8 \mathrm{~h}$ and at $3 \mathrm{~h}$ into their dark cycle were then infused with vehicle $(0.5 \mu \mathrm{l} \mathrm{NaCl})$, raclopride $(2.2 \mu \mathrm{g}$ per $0.5 \mu \mathrm{l})$, or bromocriptine $(1 \mu \mathrm{g}$ per $0.5 \mu \mathrm{l})$ into each cannula at a rate of $0.2 \mu \mathrm{l} / \mathrm{min}$. Each mouse was tested 3 times over a 3 -week period, once per pretreatment with the above. At the end of each infusion mice were injected with $2 \mathrm{~g} / \mathrm{kg}$ glucose IP and blood glucose was assessed at 0, 30, 60, and $120 \mathrm{~min}$ after injection using a commercial handheld glucometer.

\section{Data Analysis from BXD Mouse Database}

Data from BXD recombinant mice were accessed via www. genenetwork.org. All data were downloaded and utilized as per the website guidelines. $\left[{ }^{125} \mathrm{I}\right]$ epidepride binding in the NAc shell (ID: 10222), NAc core (ID: 10221), and CPu (ID: 10220) were correlated with area under curve values during IPGTT (ID: 12896) using mean values derived from males from eight different strains. Relationships among all 
variables were assessed via initial rank order transformation of the data followed by linear regression analysis.

\section{Statistics}

Depending on the experiment, paired/unpaired $t$-tests or single/multifactor ANOVAs with Holm-Sídák or Fisher's LSD post hoc tests were used, taking repeated measures into account where appropriate. Only significant effects are reported. All statistical tests were evaluated at the $p \leqslant 0.05$ level. All data are expressed as mean \pm SEM.

\section{RESULTS}

D32 $2^{\mathrm{fl} / \mathrm{fl}} / \mathrm{D} 2 \mathrm{cre}^{+}$Mice Exhibit Transcriptional and Functional D2R Adaptations in the NAc Consistent with Increased D2R Activation

We examined Drd 2 mRNA expression in the $\mathrm{CPu}$ and NAc and observed that compared with controls, D32 $2^{\mathrm{fl} / \mathrm{fl}} / \mathrm{D} 2 \mathrm{cre}^{+}$ mice had significantly greater NAc D2R mRNA expression $(t=2.82 ; p=0.013)$ (Figure 1a and $\mathrm{b})$. Next, we compared the functional state of $\mathrm{D} 2 \mathrm{R}$ between the two strains via quinpirole-stimulated $\left[{ }^{35} \mathrm{~S}\right] \mathrm{GTP} \gamma \mathrm{S}$ autoradiography. We did not observe any basal differences in $\left[{ }^{35} \mathrm{~S}\right] \mathrm{GTP} \gamma \mathrm{S}$ binding between the two strains. However, and in agreement with mRNA expression differences, we observed significantly greater quinpirole-stimulated $\left[{ }^{35} \mathrm{~S}\right] \mathrm{GTP} \gamma \mathrm{S}$ binding in the $\mathrm{NAcSh}$ of $\mathrm{D} 32^{\mathrm{fl} / \mathrm{fl}} / \mathrm{D} 2 \mathrm{cre}^{+}$mice compared with controls $(t=4.07 ; p=0.026)$ (Figure 1c-e).

\section{D32 $2^{\mathrm{fl} / \mathrm{fl}} / \mathrm{D} 2 \mathrm{cre}^{+}$Mice Exhibit Increased Responding for Sucrose}

We used $\mathrm{D} 32^{\mathrm{fl} / \mathrm{fl}} / \mathrm{D} 2 \mathrm{cre}^{+}$and $\mathrm{D} 32^{\mathrm{fl} / \mathrm{fl}} / \mathrm{D} 2 \mathrm{cre}^{-}$mice to assess the contribution of D2R signaling to sucrose reinforcement by examining operant responding for sucrose pellets. Mice were assessed for differences in operant responding for sucrose pellets using an FR1 self-administration schedule. The two strains did not differ in body weight (Figure 2a), and consistent with prior findings (Bateup et al, 2010) D32 $2^{\mathrm{fl} / \mathrm{fl}} /$ $\mathrm{D} 2 \mathrm{cre}^{+}$mice exhibited significantly greater locomotor activity (Genotype: $(\mathrm{F}(1,19)=8.61, p=0.008$; Session: $(\mathrm{F}$ $(8,152)=10.94, p<0.001)$ (Figure $2 b$ ). Both groups quickly learned to distinguish between the active (sucrose) and inactive (no pellet) lever, with $\mathrm{D} 32^{\mathrm{fl} / \mathrm{fl}} / \mathrm{D} 2 \mathrm{cre}^{+}$mice exhibiting significantly greater active (but not inactive) lever responding (Genotype: $\mathrm{F}(1,19)=10.91, \quad p=0.004$; Session: $\mathrm{F}$ $(8,152)=37.86, p<0.001$; Interaction (genotype $\times$ session): $\mathrm{F}(8,152)=7.55, p<0.001$ ) (Figure $2 \mathrm{c}-\mathrm{e}$ ) and significantly lower response latency for the active lever $(t=3.13$; $p=0.005$ ) (Figure 2f).

\section{D32 ${ }^{\mathrm{fl} / \mathrm{fl}} / \mathrm{D} 2 \mathrm{cre}^{+}$Mice Exhibit Increased Impulsive Choice Behavior for Sucrose}

Mice were first trained to lever press (FR1) on two distinct levers for receipt of a sucrose pellet (pretraining phase). During pretraining, mice in both groups acquired the lever pressing behavior with increased training experience (Session: $\mathrm{F}(9,210)=13.28, p<0.001$ ) (Figure 3a). ANOVA revealed a main effect of genotype $(F(1,210)=110.31$, $p<0.001)$ indicating that, consistent with our prior data, total active lever pressing was significantly greater in $\mathrm{D} 32^{\mathrm{fl} / \mathrm{fl}}$ / $\mathrm{D} 2 \mathrm{cre}^{+}$mice than in controls. As above, D32 $2^{\mathrm{fl} / \mathrm{fl}} / \mathrm{D} 2 \mathrm{cre}^{+}$mice exhibited significantly greater locomotor activity (Figure $3 \mathrm{~b}$ ). Impulsive choice behavior for sucrose was assessed in $\mathrm{D} 32^{\mathrm{fl} / \mathrm{fl}} / \mathrm{D} 2 \mathrm{cre}^{+}$mice and controls using the ITD task (Figure 3c). Animals that met lever pressing criteria during the pretraining stage ( $79 \%$ of controls (11 out of 14$)$ and $100 \%$ of mutants (12 out of 12$)$ ) moved on to the ITD
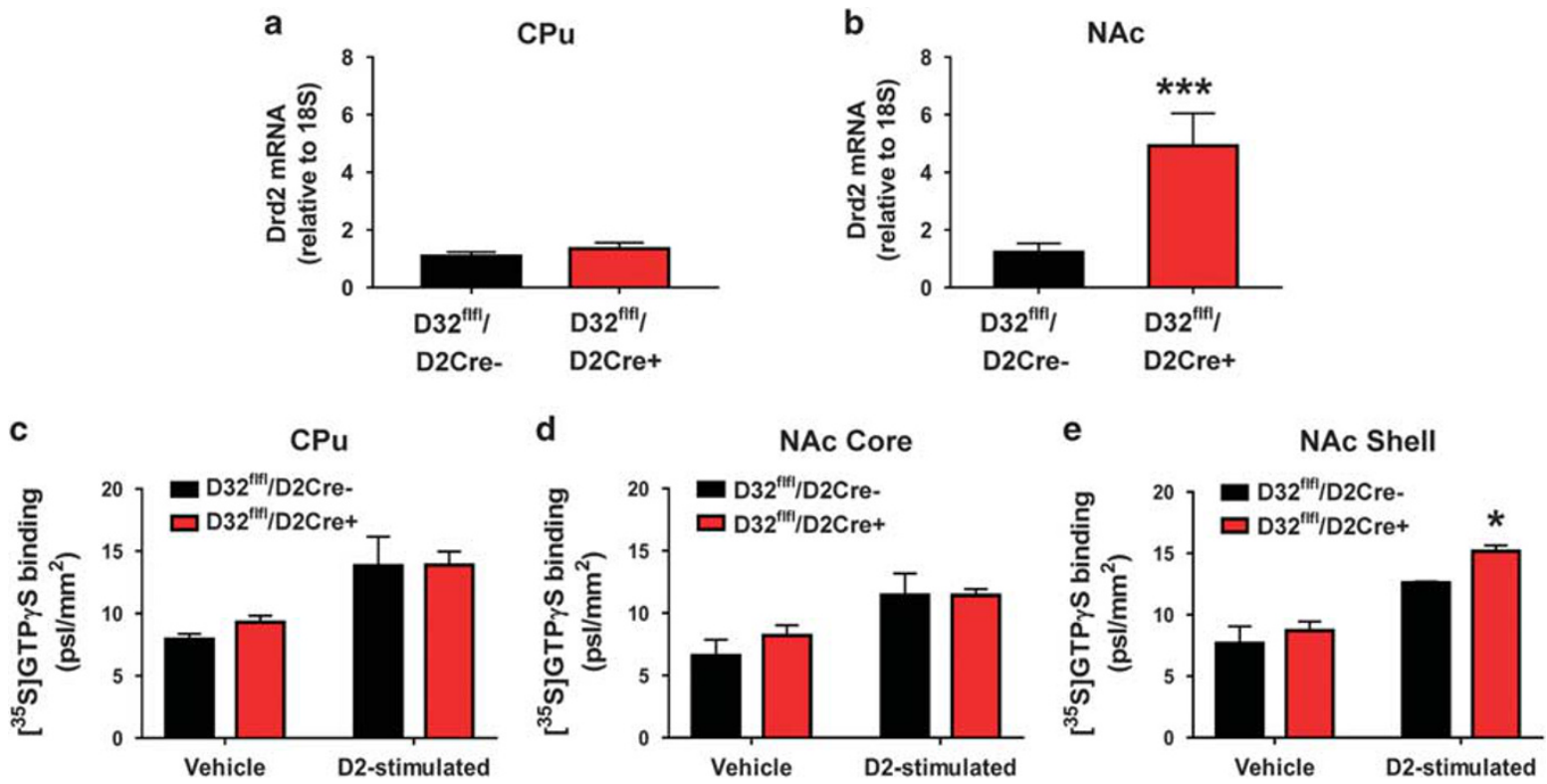

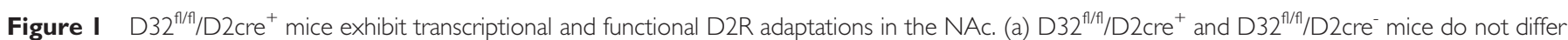
in Drd2 mRNA expression in the CPu but (b) D32 $2^{f / f} / D 2 c r e{ }^{+}$show significantly greater Drd2 mRNA expression in the NAc. ***** $\leqslant 0.001$, two-sample

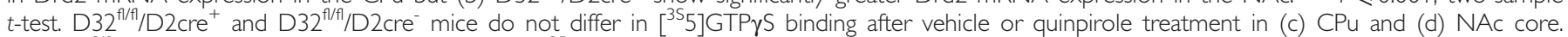
(e) D32 $2^{\mathrm{f} / f /} / \mathrm{D} 2 \mathrm{cre}^{+}$mice exhibit significantly greater $\left[{ }^{35} \mathrm{~S}\right] \mathrm{GTP} \gamma \mathrm{S}$ binding in response to quinpirole in the NAc Shell compared with controls. $* P \leqslant 0.05$, two-sample $t$-test. Data are shown as mean \pm SEM. 

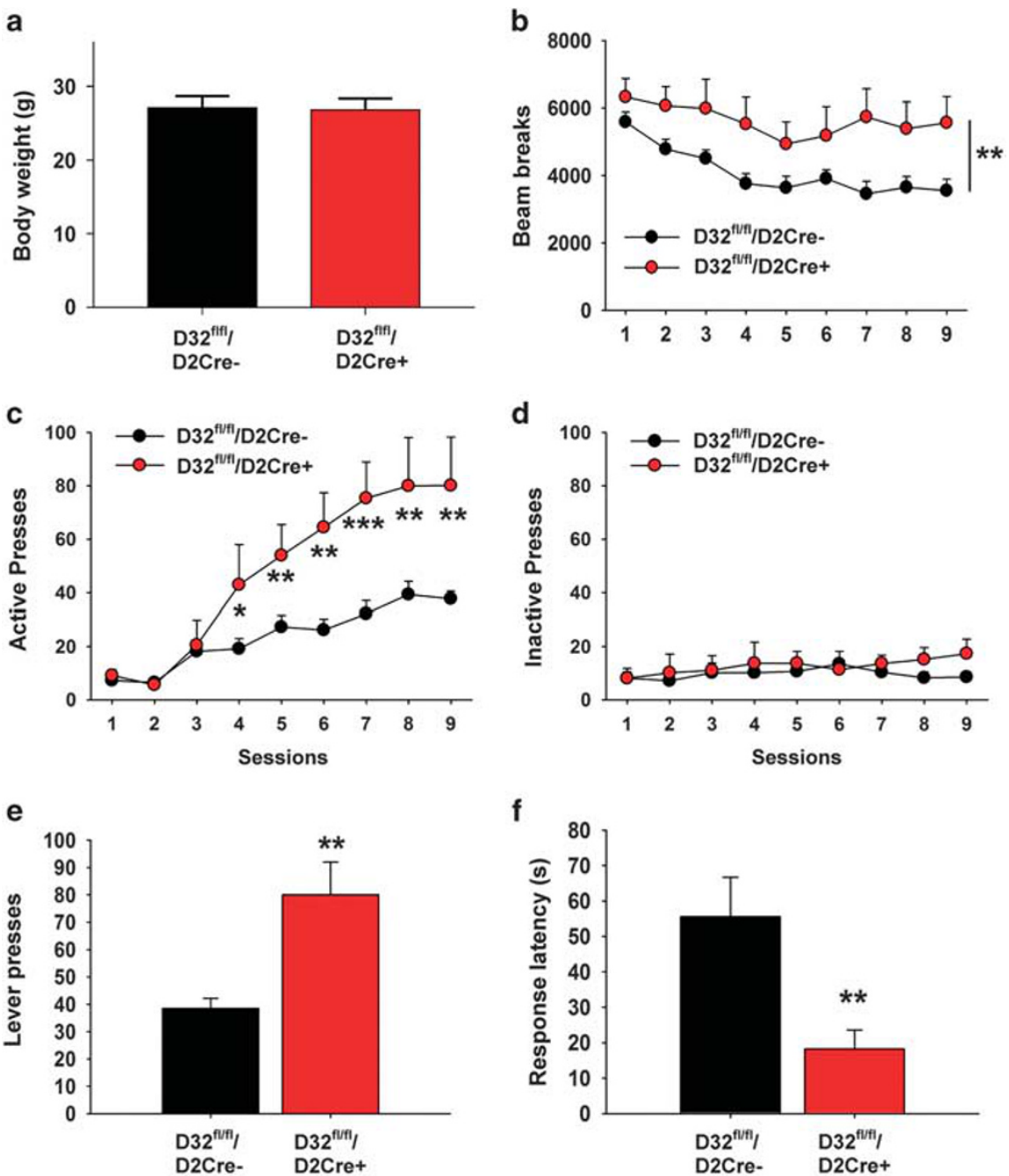

Figure $2 \mathrm{D} 32^{f / f / 1} / \mathrm{D} 2 \mathrm{cre}{ }^{+}$mice exhibit increased responding for sucrose. (a) D32 $2^{f / f} / \mathrm{D} 2 \mathrm{cre} e^{+}$and D32 $2^{f / f} / \mathrm{D} 2 \mathrm{cre} e^{-}$mice did not differ in body weight. (b)

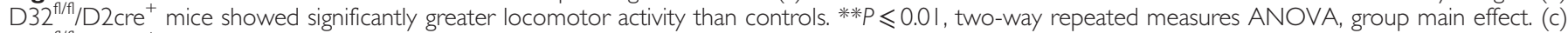

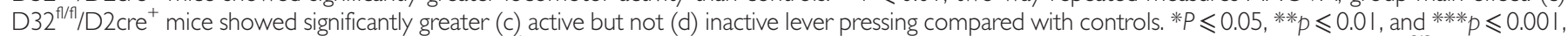
two-way repeated measures ANOVA with Holm-Śídák post hoc tests. (e) Across sessions 8 and 9 (when lever pressing was most stable), D32 $2^{f / f / 1} / \mathrm{D} 2 \mathrm{cre} \mathrm{f}^{+}$mice showed twice as many active lever presses and ( $f$ ) significantly lower active lever response latency than controls $* * * \leqslant 0.05$, two-sample $t$-test. Data are shown as mean $\pm \mathrm{SEM}$.

training stage where they learned to differentiate between the two levers based on reward magnitude (a response on one lever resulted in the delivery of 1 food pellet (L1), whereas pressing the other lever resulted in the delivery of 5 food pellets (L5)). As the same amount of effort (1 lever press) could result in either 1 or 5 pellets, animals were expected to develop a preference for L5, and this was in fact observed in $73 \%$ of controls ( 8 out of 11 ) and $67 \%$ of mutants ( 8 out of 12). These animals moved onto the ITD testing stage where impulsive food-choice behavior was assessed by measuring the percent choice of L5 presses across increasing delays to pellet delivery. As expected, when there was no delay between L5 lever pressing and sucrose delivery, mice developed a preference for the large reinforcer (Genotype: $\mathrm{F}(1,112)=16.45, p<0.001)$ (Figure 3d). However, as the delay to sucrose delivery increased, percent choice of the large reinforcer decreased, with $\mathrm{D} 32^{\mathrm{H} / \mathrm{fl} /} / \mathrm{D} 2 \mathrm{cre}^{+}$mice showing increased delay discounting (ie, increased impulsive choice) compared with controls (Figure 3d). Increased impulsive food-choice behavior in $\mathrm{D} 32^{\mathrm{fl} / \mathrm{fl}} / \mathrm{D} 2 \mathrm{cre}^{+}$mice was further determined by assessing L5 vs L1 preference reversal (delay at which mice shifted their preference from the L5 to the L1 lever; Green and Estle, 2003). D $32^{\mathrm{fl} / \mathrm{fl}} / \mathrm{D} 2 \mathrm{cre}^{+}$mice reversed their preference from L5 to L1 when the delay was set to $100 \mathrm{~s}$ (Interaction (lever $\times$ delay time): $\mathrm{F}(7,112)=3.7$, $p=0.001$ ) (Figure 3f), whereas control mice did not (Figure 3e).

\section{D32 ${ }^{\mathrm{fl} / \mathrm{fl}} / \mathrm{D} 2 \mathrm{cre}^{+}$Mice Exhibit Sustained Glucose Reinforcement Learning and Impaired Learning Flexibility}

Sucrose is composed of 1:1 parts glucose and fructose. Glucose has significant metabolic and orosensory reinforcement properties, whereas fructose conveys orosensory but lacks metabolic reinforcement (Sclafani et al, 1993). As food reward is primarily driven by metabolic and less so by orosensory reinforcement (de Araujo, 2011), mice readily prefer glucose over fructose (Sclafani and Ackroff, 2012). 
a

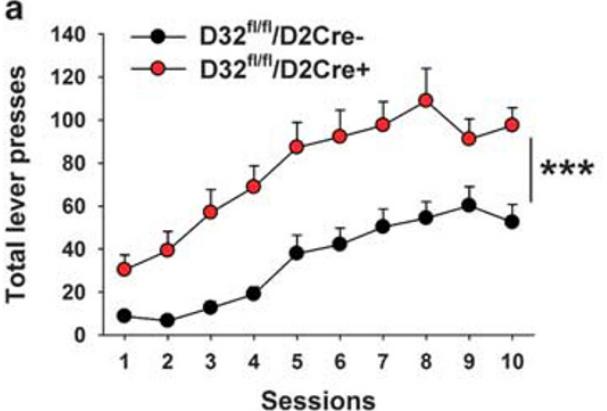

C

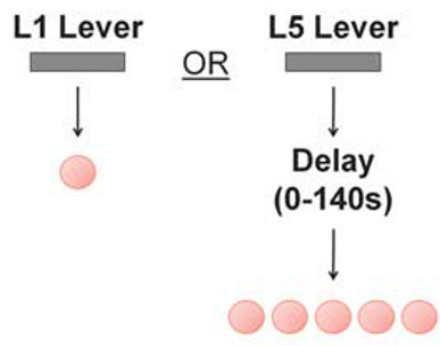

e

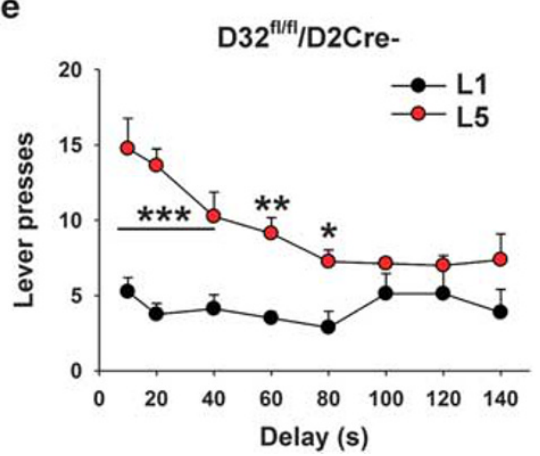

b

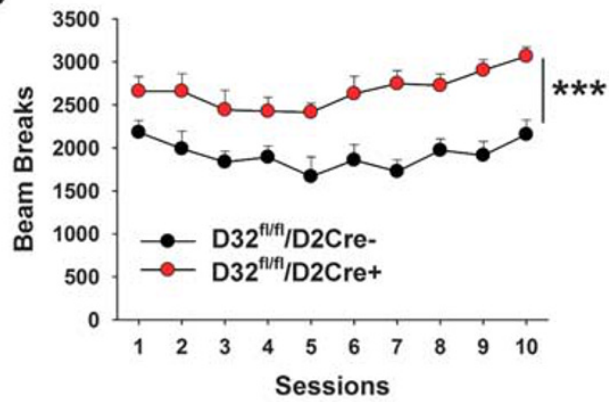

d

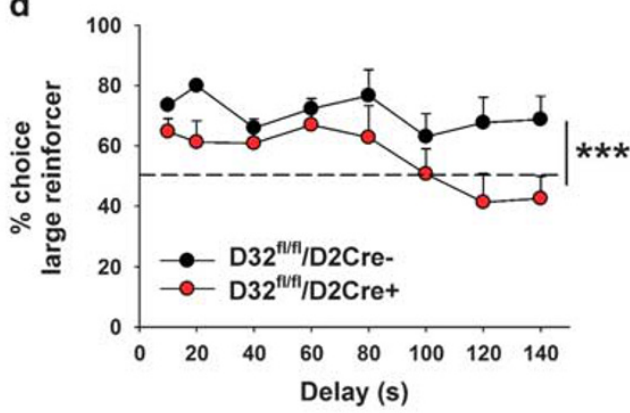

f

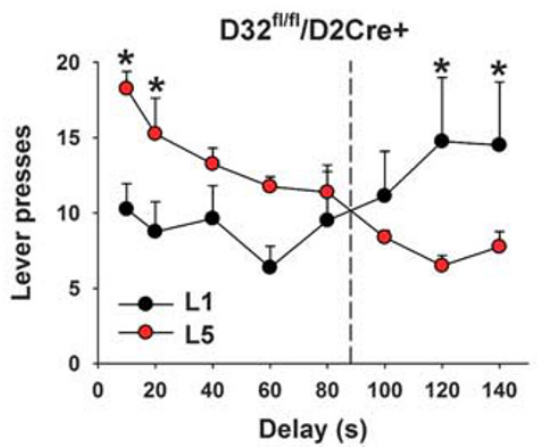

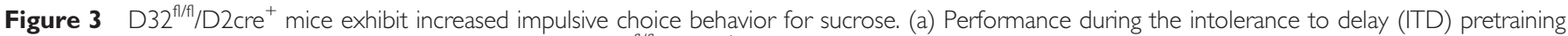
stage. Total lever pressing was significantly greater in D32/f/l/D2cre ${ }^{+}$mice than in controls. **** $P \leqslant 0.001$, one-way ANOVA. (b) During training,

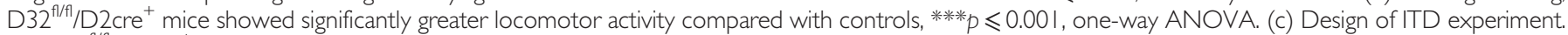
(d) D32/f/l/D2cre ${ }^{+}$mice showed significantly lower \% choice for the large reinforcer as a function of increasing delay compared with controls, **** $p \leqslant 0.00 \mathrm{I}$, two-way repeated measures ANOVA, group main effect. (e) Control mice showed significantly greater pressing for L5 over LI levers. *P $\leqslant 0.05$, *** $p \leqslant 0.01$, and **** $p \leqslant 0.00 \mathrm{I}$, two-way repeated measures ANOVA with Holm-Šídák post hoc tests. (f) D32 ${ }^{f / f l} / \mathrm{D} 2 \mathrm{cre}^{+}$mice showed significantly greater pressing for L5 over LI levers at short delay intervals and significantly higher LI vs L5 lever pressing at longer delay intervals. *P $\leqslant 0.05$, two-way repeated measures ANOVA with Holm-Šídák post hoc tests. Data are shown as mean \pm SEM.

Our above results suggested that D2Rs regulate sucrose reinforcement, but the extent to which this was driven by glucose or fructose was not known. Therefore, we compared glucose $v s$ fructose intake and conditioned reinforcement learning behavior for each nutrient in $\mathrm{D} 32^{\mathrm{f} / / \mathrm{fl}} / \mathrm{D} 2 \mathrm{cre}^{+}$mice and controls using a conditioned flavor preference paradigm (Figure 4a). After establishing baseline preference for two distinct flavors (grape $v s$ cherry) (Figure $4 \mathrm{~b}$ ), mice were given access to glucose-grape- and fructose-cherry-flavored solutions. As expected, both strains (D32 $2^{\mathrm{f} / \mathrm{fl}} / \mathrm{D} 2 \mathrm{cre}^{-}: t=11.06$, $\left.p<0.001 ; \quad \mathrm{D} 32^{\mathrm{fl} / \mathrm{fl}} / \mathrm{D} 2 \mathrm{cre}^{+}: \quad t=13.67, \quad p<0.001\right)$ consumed significantly more grape-paired glucose compared with cherry-paired fructose (Figure $4 \mathrm{c}$ and $\mathrm{d}$ ). In agreement with increased sucrose seeking, D32 $2^{\mathrm{fl} / \mathrm{fl} /} / \mathrm{D} 2 \mathrm{cre}^{+}$mice exhibited significantly greater intake for grape-paired glucose compared with controls $(t=3.69, p<0.001)$ (Figure $4 \mathrm{c})$, but no strain difference in cherry-paired fructose intake was observed (Figure 4d). After nutrient-flavor conditioning, both groups readily associated each flavor with its respective paired nutrient, as in the absence of glucose, both consumed significantly more of grape-paired fructose over cherrypaired fructose $\left(\mathrm{D} 32^{\mathrm{fl} / \mathrm{fl}} / \mathrm{D} 2 \mathrm{cre}-: \quad t=6.29, \quad p<0.001\right.$; $\left.\mathrm{D} 32^{\mathrm{fl} / \mathrm{fl}} / \mathrm{D} 2 \mathrm{cre}^{+}: t=9.28, p<0.001\right)$ (Figure 4e). Importantly, $\mathrm{D} 32^{\mathrm{f} / / \mathrm{fl}} / \mathrm{D} 2 \mathrm{cre}^{+}$mice consumed significantly more of the grape-paired (but not cherry-paired) fructose than controls $(t=2.95, p=0.006)$ (Figure 4e). Striatal D2Rs (Yawata et al, 2012) are implicated in food reward learning flexibility (ie, reversal learning) but their specific role in learning flexibility of glucose and/or fructose-paired flavors was unknown. To examine this, we switched the original flavor-nutrient pairings and repeated the above experiment. As expected, D $32^{\mathrm{f} / \mathrm{fl}} / \mathrm{D} 2 \mathrm{cre}^{+}$mice and controls switched their 

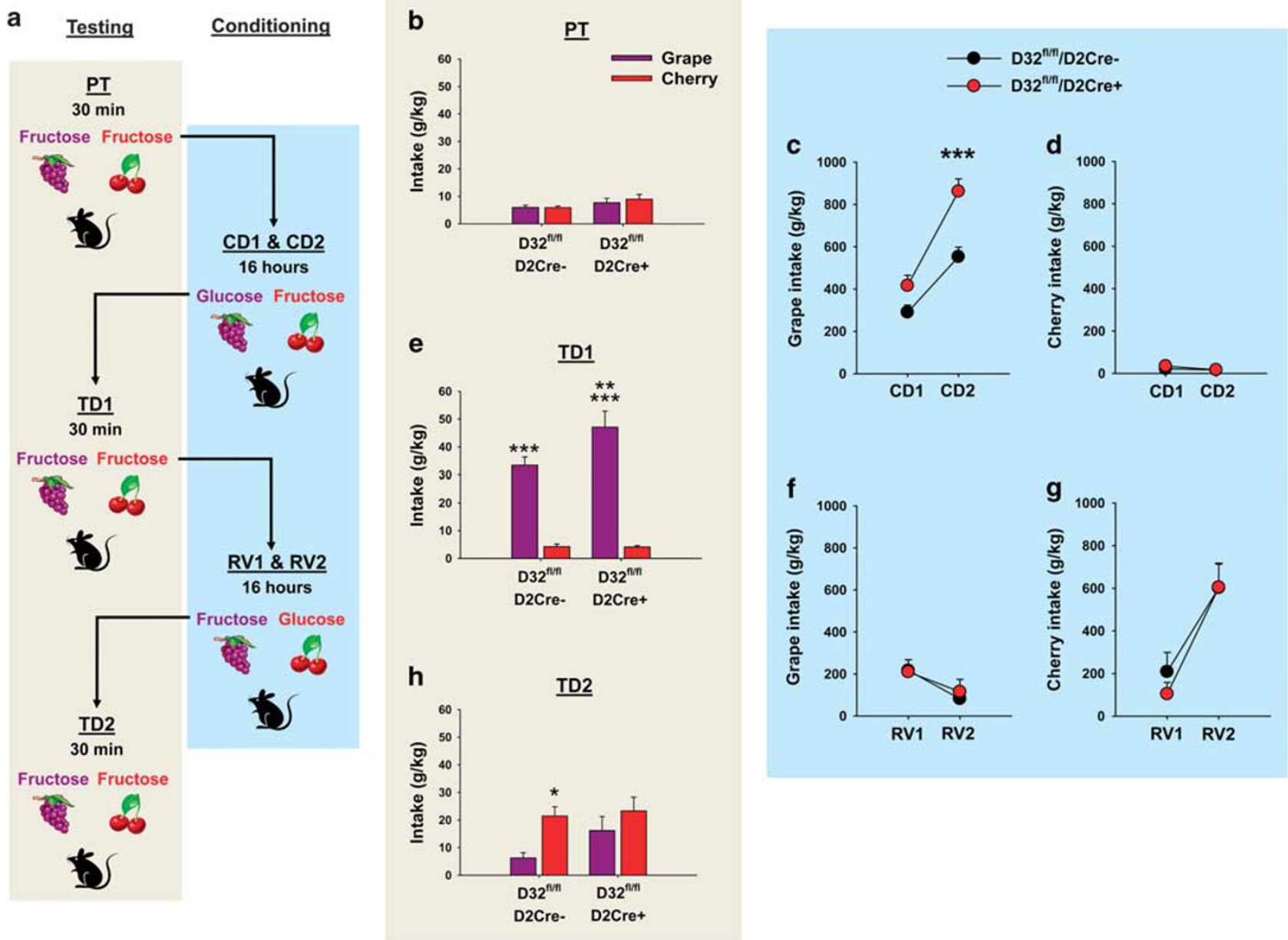

Figure $4 \mathrm{D} 32^{\mathrm{f} / \mathrm{fl}} / \mathrm{D} 2 \mathrm{cre}^{+}$mice exhibit sustained glucose-derived reinforcement learning and impaired learning flexibility. (a) Design of conditioned flavor preference experiment (PT, pretest; CDI, conditioning day I; CD2, conditioning day 2; RVI, reversal conditioning day I; RV2, reversal conditional day 2). (b)

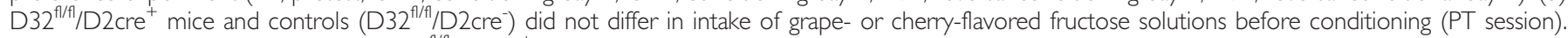
During conditioning (CDI and CD2), D32/f/f/D2cre mice consumed significantly more (c) grape-paired glucose but not (d) cherry-paired fructose vs controls. **** $P \leqslant 0.00$ I, two-sample $t$-test. Both groups consumed more grape-paired glucose over cherry-paired fructose. (e) After conditioning (TDI), D32 ${ }^{\text {fl/fl/D2 }} / \mathrm{cre}^{+}$ and control mice consumed significantly more grape-flavored fructose compared with cherry-flavored fructose. $* * * * P \leqslant 0.001$, paired $t$-test. D $32^{f / f / 1} / \mathrm{D} 2 \mathrm{cre}{ }^{+}$ mice consumed significantly more grape-flavored fructose vs controls, whereas the two groups did not differ in cherry-paired fructose intake. *** $\leqslant 0.01$, twosample $t$-test. During reversal conditioning, D32 $/ / 1 / \mathrm{D} 2 \mathrm{cre}^{+}$and controls did not differ in (f) grape-paired fructose or (g) cherry-paired glucose intake. Both groups readily consumed more cherry-paired glucose compared with grape-paired fructose solutions. (h) After reversal conditioning, controls readily consumed more cherry-paired fructose over grape-paired fructose but D $32^{\mathrm{fl} / \mathrm{t}} / \mathrm{D} 2 \mathrm{cre} \mathrm{e}^{+}$mice did not. $* P \leqslant 0.05$, paired $t$-test. Data are shown as mean \pm SEM.

initial intake profiles to consume significantly more of the novel cherry-paired glucose over the novel grape-paired fructose solution (D32 $2^{\mathrm{fl} / \mathrm{fl}} / \mathrm{D} 2 \mathrm{cre}^{-}: t=3.45, p=0.009 ; \mathrm{D} 32^{\mathrm{fl} / \mathrm{fl} /}$ D2 $\left.\mathrm{cre}^{+}: t=2.98, p=0.01\right)$. In contrast to the original conditioning sessions, no difference in intake between the two groups was observed (Figure $4 \mathrm{f}$ and g). Interestingly, in the absence of glucose, controls consumed significantly more of the cherry-paired fructose over the grape-paired fructose, indicating that they successfully associated the novel flavornutrient pairings $(t=2.64, p=0.01)$ (Figure $4 \mathrm{~h})$. In contrast, $\mathrm{D} 32^{\mathrm{fl} / \mathrm{fl}} / \mathrm{D} 2 \mathrm{cre}^{+}$mice did not (Figure $\left.4 \mathrm{~h}\right)$. This behavior was not driven by impaired association of the novel nutrientflavor pairing, as both groups consumed equal amounts of the cherry-paired solution. In contrast, the impaired discrimination profile of $\mathrm{D} 32^{\mathrm{fl} / \mathrm{fl}} / \mathrm{D} 2 \mathrm{cre}^{+}$mice was driven by perseverative intake of the flavor originally paired with glucose (ie, grape).

\section{D32 ${ }^{\mathrm{fl} / \mathrm{fl}} / \mathrm{D} 2 \mathrm{cre}^{+}$Mice Exhibit Impaired Glucose Tolerance and Pharmacological Modulation of D2R Signaling in the NAc Alters Glucose Tolerance}

Systemic administration of D2R agonists is known to increase glucose intolerance and lead to increased blood glucose levels (de Leeuw van Weenen et al, 2010; Garcia-Tornadu et al, 2010; Saller and Kreamer, 1991; Schmidt et al, 1983). In consideration of our current observations, these prior findings suggested that increased sucrose reinforcement and glucose-derived reinforcement learning behaviors observed in $\mathrm{D} 32^{\mathrm{fl} / \mathrm{fl}} / \mathrm{D} 2 \mathrm{cre}^{+}$mice may be driven, in part, by general impairment in glucose tolerance. First, we leveraged the BXD recombinant mouse database (www.genenetwork.org) that includes data sets from BXD strains exposed to IPGTT as well as D2R density measurements ([ $\left.{ }^{125} \mathrm{I}\right]$ epidepride binding) in the $\mathrm{CPu}, \mathrm{NAcSh}$, and NAcC. Using these data sets, we observed that D2R binding 

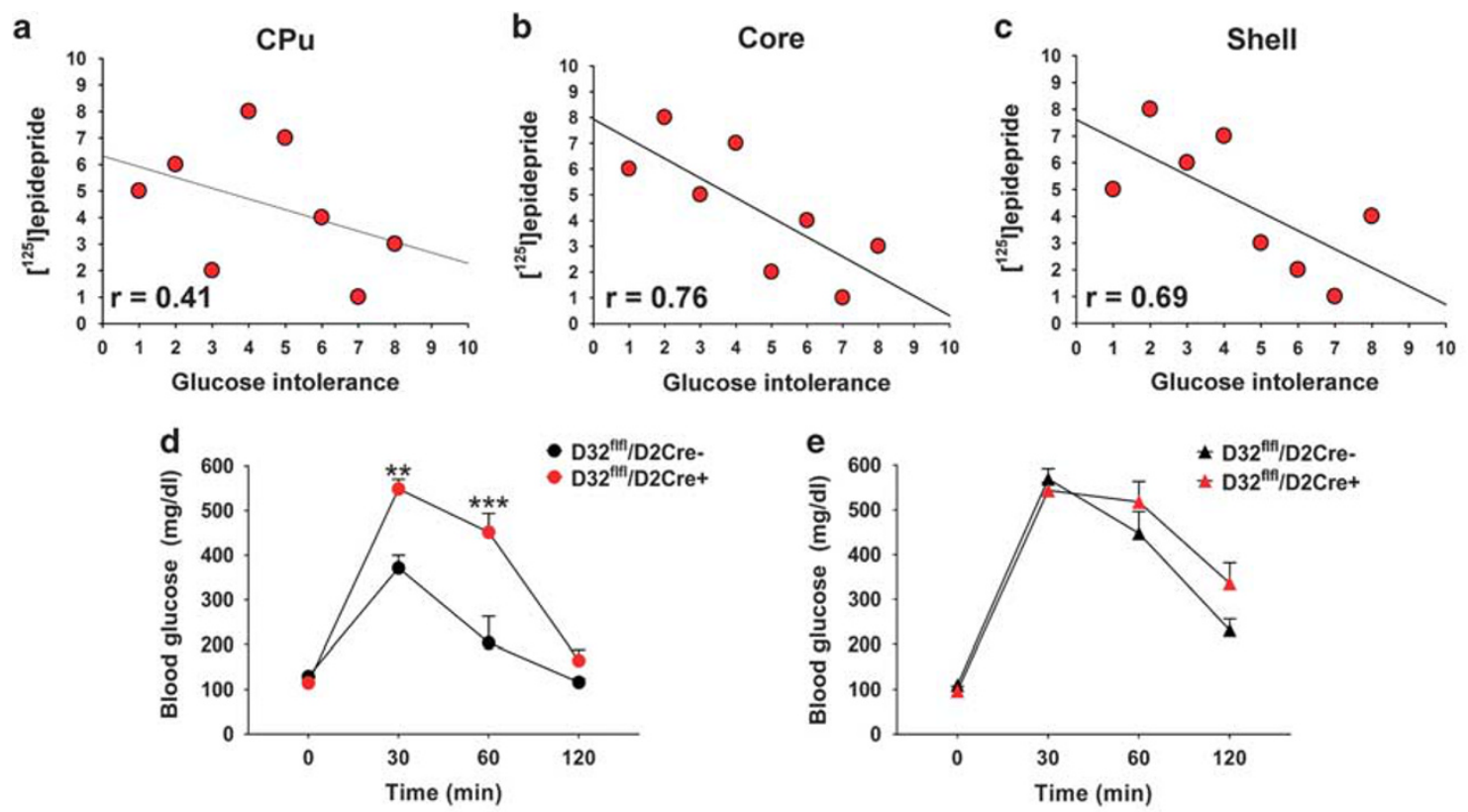

f

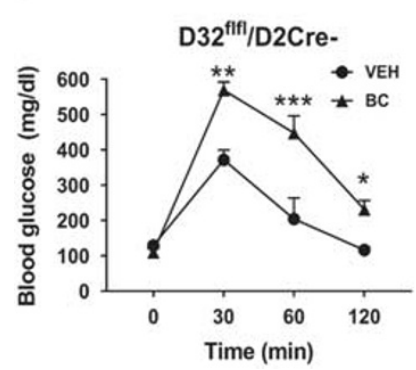

g

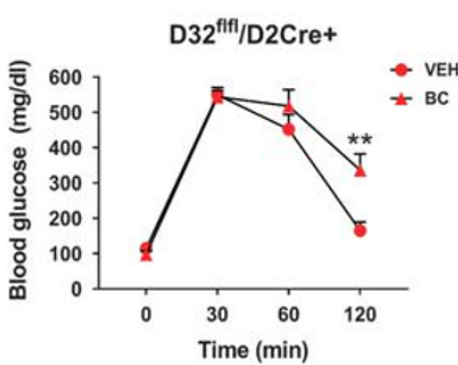

h

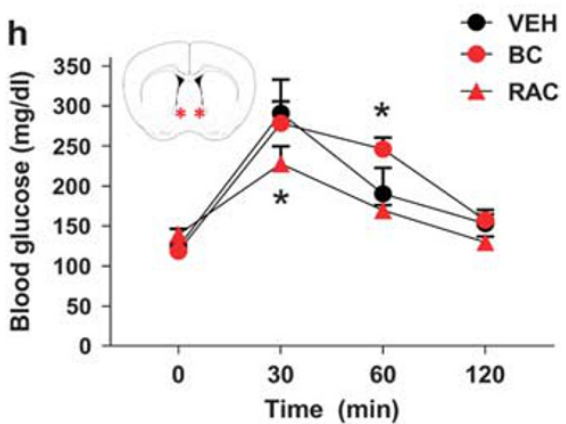

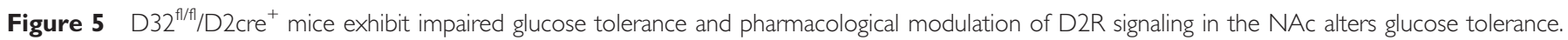
(a) D2R binding in CPu shows mild correlation with glucose intolerance (area under the curve of a 120 min intraperitoneal glucose tolerance test) in BXD recombinant mice. $(b, c) D 2 R$ binding in NAc core and NAc shell correlates strongly with glucose intolerance. (d) D32/f/l /D2cre ${ }^{+}$mice exhibit significantly greater glucose intolerance compared with controls but this difference is ameliorated by bromocriptine (BC; 10 mg/kg) (e). More specifically, BC significantly increases glucose intolerance in controls ( $\mathrm{f}$ ) but fails to produce similar effects in (g) D32 ${ }^{\mathrm{fff}} / \mathrm{D} 2 \mathrm{cre}{ }^{+}$mice (vehicle (Veh)). $* P \leqslant 0.05$, $* * * \leqslant 0.01$, and ***** $p \leqslant 0.00$ I, two-way repeated measures ANOVA with Holm-Šídák post hoc tests. (h) BC or raclopride (RAC) injected directly into the bilateral NAc (schematic showing injection targeting) respectively leads to a significant increase and decrease in glucose intolerance. * $P \leqslant 0.05$, two-way repeated measures ANOVA with Holm-Šídák post hoc tests. Data are shown as mean \pm SEM.

in the NAcSh and NAcC (but less so in $\mathrm{CPu}$ ) significantly correlated with glucose tolerance (Figure 5a-c). These findings prompted us to examine the extent to which $\mathrm{D} 32^{\mathrm{f} / \mathrm{fl}} / \mathrm{D} 2 \mathrm{cre}^{+}$mice exhibited impairments in striatal D2R. Given the preferential D2R disruptions in NAc and the BXD results, we next compared glucose intolerance between $\mathrm{D} 32^{\mathrm{fl} / \mathrm{fl}} / \mathrm{D} 2 \mathrm{cre}^{+}$mice and controls via IPGTT. We found that $\mathrm{D} 32^{\mathrm{fl} / \mathrm{fl}} / \mathrm{D} 2 \mathrm{cre}^{+}$animals exhibited significantly greater glucose intolerance (Strain: $\mathrm{F}(1,35)=21.71, p=0.002$; Time: $\mathrm{F}$ $(3,43)=82.97, \quad p<0.001 ; \quad$ Interaction $\quad$ (strain $\times$ time): $\mathrm{F}(6,43)=13.8, \quad p<0.001) \quad$ compared with controls (Figure 5d). In agreement with prior studies where systemic administration of D2R agonists increased glucose intolerance (Garcia-Tornadu et al, 2010; Pizzolato et al, 1985; Schmidt et al, 1983), we found that systemic exposure to the D2R agonist bromocriptine significantly increased glucose intolerance in controls but had much less pronounced effects in $\mathrm{D} 32^{\mathrm{fl} / \mathrm{fl}} / \mathrm{D} 2 \mathrm{cre}^{+}$mice (Figure $5 \mathrm{e}-\mathrm{g}$ ). Given both the impaired glucose tolerance and the D2R disturbances in the NAc of $\mathrm{D} 32^{\mathrm{fl} / \mathrm{fl}} / \mathrm{D} 2 \mathrm{cre}^{+}$mice, we examined whether pharmacological modulation of D2R signaling specifically in the NAc in C57/ Bl6 mice $(n=4-5)$ would affect glucose tolerance. Mice were cannulated targeting the bilateral NAc and assessed on the IPGTT paradigm. Each mouse was assessed three times in counterbalanced order after vehicle, bromocriptine, or raclopride infusions into the NAc. In agreement with our above data, bromocriptine led to a mild but significant increase in glucose intolerance at $60 \mathrm{~min}(t=3.04 ; p=0.039)$ after glucose injection (Subject: $\mathrm{F}(1,4)=0.38, p=0.57$; Time: $\mathrm{F}(3,12)=19.98, \quad p<0.001 ; \quad$ Interaction (subject $\times$ time): $\mathrm{F}(3,12)=2.86, p=0.08)$. In contrast, raclopride produced a significant decrease (Subject: $\mathrm{F}(1,3)=2.52, p=0.21$; Time: $\mathrm{F}(3,9)=39.93, \quad p<0.001 ; \quad$ Interaction (strain $\times$ time): $\mathrm{F}(3,9)=2.11, p=0.17)$ in glucose intolerance that was observed at $30 \mathrm{~min}(t=3.16, p=0.045)$ after glucose injection (Figure 5h). 


\section{Pharmacological Activation of D2R Accentuates the Inhibitory Effects of Glucose on Operant Responding for Sucrose Pellets}

In an effort to link glucose tolerance to sucrose reinforcement, naive C57/Bl6 mice were trained to lever press on an FR1 sucrose pellet operant task similar to the one employed in $\mathrm{D} 32^{\mathrm{f} / \mathrm{fl}} / \mathrm{D} 2 \mathrm{cre}^{+}$and $\mathrm{D} 32^{\mathrm{fl} / \mathrm{fl}} / \mathrm{D} 2 \mathrm{cre}^{-}$mice from our above experiments. Once mice exhibited stable responding and clear discrimination for the active lever, they were exposed to four consecutive operant sessions, designed to mimic conditions of the above IPGTT paradigm. In particular, mice were fasted for $\sim 6 \mathrm{~h}$ and then at $3 \mathrm{~h}$ into their dark cycle were pretreated with an IP injection of either vehicle or bromocriptine $(10 \mathrm{mg} / \mathrm{kg})$ and $15 \mathrm{~min}$ later injected again IP with either vehicle or glucose $(2 \mathrm{~g} / \mathrm{kg})$ and then tested for sucrose pellet self-administration for $150 \mathrm{~min}$ (Figure 6a). Each mouse was exposed to four consecutive sessions: vehicle/vehicle, vehicle/glucose, vehicle/vehicle, and bromocriptine/glucose.

Lever presses. (Treatment: $\mathrm{F}(3,18)=12.83, \quad p=0.001$; Time: $\mathrm{F}(4,24)=6.69, p=0.009$; Interaction (treatment $\times$ time): $\mathrm{F}(12,72)=3.51, p=0.004)$. During both vehicle/ vehicle sessions, mice showed a fluctuating temporal profile for sucrose pellet responding that comprised high responding on the active lever during the first $30 \mathrm{~min}$, followed by a decrease in lever pressing at $60 \mathrm{~min}$, then a second increase at $90 \mathrm{~min}$ into the session, and finally stable lever pressing after $120 \mathrm{~min}$ (Figure 6b). In contrast, during the vehicle/glucose session mice showed significantly decreased lever pressing at discrete time points, in particular those corresponding to the peak lever pressing during vehicle (ie, $30(p=0.019)$ and $90 \mathrm{~min}(p=0.008)$ ) sessions (Figure $6 \mathrm{~b})$, suggesting that a rise in circulating glucose levels (similar to IPGTT glucose effects) decreases the reinforcing properties of sucrose. Our above observations indicated the bromocriptine leads to significantly decreased glucose tolerance and thus we anticipated that bromocriptine pretreatment followed by glucose would accentuate the effects observed during the vehicle/glucose session. Indeed, as expected, bromocriptine pretreatment followed by glucose further accentuated the inhibitory response of glucose on FR1 responding for sucrose pellets that included significantly decreased lever pressing at $30 \mathrm{~min}(p<0.001)$ and $60 \mathrm{~min}(p=0.013)$ compared with vehicle/glucose sessions and significantly decreased lever pressing at $30 \mathrm{~min}(p<0.001), 60 \mathrm{~min} \quad(p=0.025)$, and $90 \mathrm{~min}(p=0.005)$ compared with vehicle/vehicle sessions (Figure 6b). In contrast, there were no significant main effects in inactive lever pressing (Figure 6c).

Pellets earned. Glucose also significantly decreased the total number of pellets earned ( $v s$ veh/veh session $1 ; t=3.73$, $p=0.009 v s \mathrm{veh} / \mathrm{veh}$ session $2 ; t=2.35, p=0.05$ ) (Figure 6d) and consumed ( $v s$ veh/veh session $1 ; t=3.29, p=0.01 v s \mathrm{veh} /$ veh session 2; $t=3.09, p=0.02$ ) (Figure 6e) compared with both vehicle/vehicle sessions. Bromocriptine (BC) further accentuated the glucose-mediated decrease in pellets earned (veh/glu vs BC/glu; $t=2.97, p=0.024$ ) (Figure 6d) and completely abolished sucrose pellet consumption (veh/glu $v s$ BC/glu; $t=10.34, p<0.001$ ) (Figure 6e). Given that the same bromocriptine dose significantly decreased glucose tolerance in normal mice (Figure $5 e$ and $\mathrm{f}$ ) these results suggest that bromocriptine's inhibitory effects on operant responding for sucrose may be mediated in part via its inhibitory effects on glucose tolerance. Furthermore, taken together with our observations where $\mathrm{D} 32^{\mathrm{fl} / \mathrm{fl}} / \mathrm{D} 2 \mathrm{cre}^{+}$mice showed significantly decreased glucose tolerance (Figure 5d), significantly impaired inhibition of glucose tolerance via bromocriptine (Figure 5e), but significantly enhanced FR1 responding for sucrose (Figures 2 and 3), these results further suggest that under normal conditions D2R signaling interacts with circulating glucose to decrease sucrose reinforcement and inhibit sucrose intake.

\section{DISCUSSION}

Here we showed that mice with loss of DARPP-32 in D2R MSNs were characterized by increased Drd2 mRNA and enhanced D2R activation in the NAc shell, results consistent with the notion that these mice are characterized by increased DA activity at D2R MSNs. In addition, these mice exhibited increased sucrose reinforcement, elevated impulsive choice behavior for sucrose, enhanced glucose reinforcement learning, impaired learning flexibility, and surprisingly, profound impairment in glucose tolerance, a cumulative profile consistent with D2R activation (Bateup et al, 2010; Centonze et al, 2001; Haluk and Floresco, 2009; Horvitz et al, 2001; Lindskog et al, 1999; Nishi et al, 1997), further indicating that these mice are characterized by increased DA-D2R activity in NAc.

The NAc plays a critical role in regulating reinforcement learning behavior, and peripheral glucose alters NAc neuronal activity (Delaere et al, 2013; Tsurugizawa et al, 2008) and NAc DA levels (Mark et al, 1994; Oliveira-Maia et al, 2011). Although D2R signaling in the NAc shell is known to modulate a variety of reinforcement learningrelated behaviors (Kenny et al, 2013; Kravitz and Kreitzer, 2012; Lobo and Nestler, 2011; Yawata et al, 2012), involvement of NAc D2R signaling in glucose metabolic regulation has not, to our knowledge, been previously reported. Notably, the specific DARPP-32 manipulation we used here would not be limited to selectively affecting D2R signaling in these neurons but also signaling relevant to other sites such as serotonin receptors (Diepenbroek et al, 2016; Lindskog, 2008). In fact, this may provide an explanation for the differences in glucose tolerance profiles that we observed in $\mathrm{D} 32^{\mathrm{fl} / \mathrm{ll}} / \mathrm{D} 2 \mathrm{cre}^{+}$mice as compared with mice injected with D2R ligands directly into NAc shell. Moreover, it may be that a portion of the glucose tolerance effects we observed in $\mathrm{D} 32^{\mathrm{fl} / \mathrm{fl}} / \mathrm{D} 2 \mathrm{cre}^{+}$mice may be driven in part by DARPP-32 loss in extrastriatal D2R-expressing cells as well.

Nevertheless, consistent with our findings, two recent studies reported blood glucose changes following either electrical stimulation (Diepenbroek et al, 2013) or serotonin reuptake inhibition (Diepenbroek et al, 2016) specifically in the NAc shell. These observations, in concert with the rest of our results, extend prior findings implicating striatal D2R in food learning flexibility (Haluk and Floresco, 2009; Kruzich et al, 2006; Yawata et al, 2012) and compulsive-like, perseverative feeding (Halpern et al, 2013; Yawata et al, 2012) by implicating involvement of D2R signaling in such behaviors via integration of glucose metabolic signaling and 
a

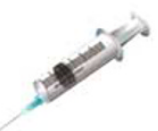

Vehicle (Veh) or

Bromocriptine (BC)

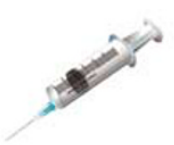

Veh or Glucose (Glu)
Sessions

1: Veh/Veh

2: Veh/Glu

3: Veh/Veh

4: BC/Glu

\begin{tabular}{lcccc}
\cline { 2 - 4 } Time & -15 & 0 & Self-administration & 150 \\
$(\min )$ & & & FR1 &
\end{tabular}

\section{b}
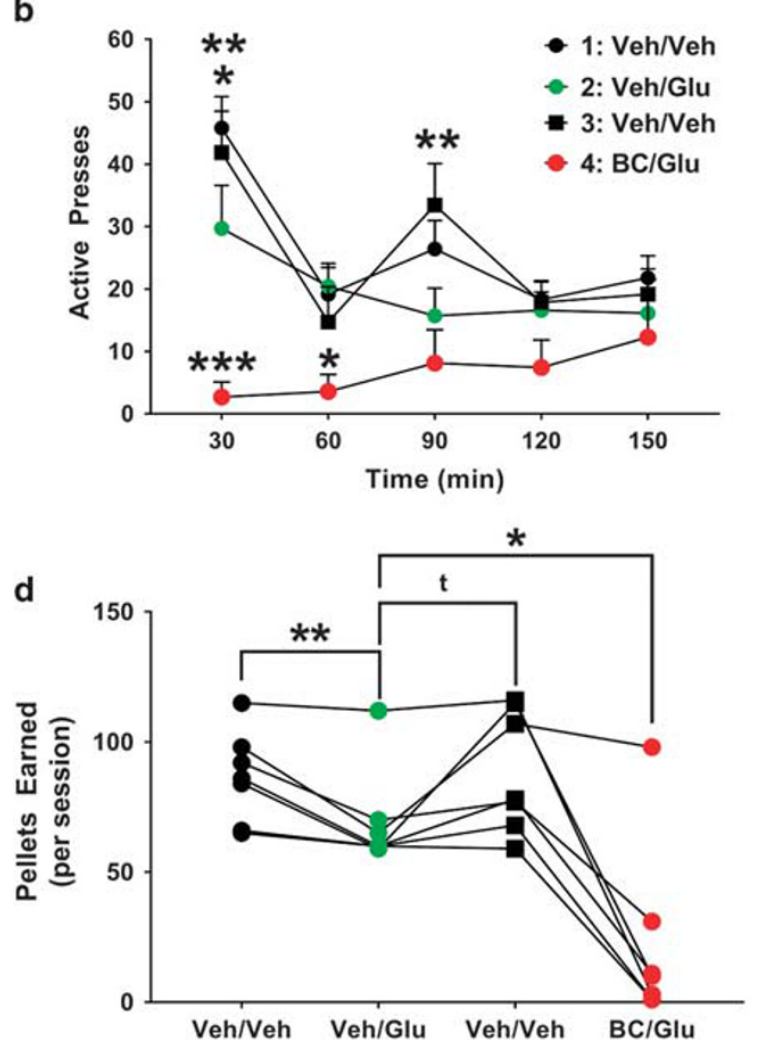

C
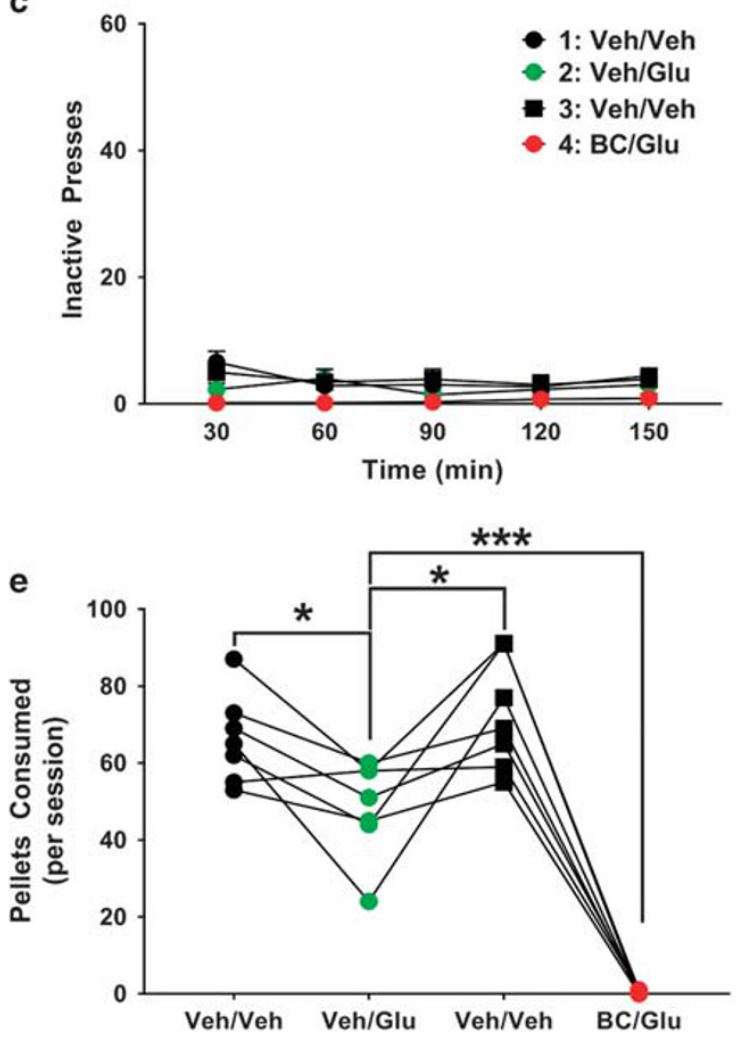

Figure 6 Pharmacological activation of D2 receptors accentuates the inhibitory effects of glucose on operant responding for sucrose pellets. (a) Experimental design: mice were injected IP with either vehicle (Veh) or bromocriptine (BC; $10 \mathrm{mg} / \mathrm{kg}$ ) and I 5 min later injected again IP with Veh or glucose (Glu; $2 \mathrm{~g} / \mathrm{kg}, \mathrm{IP}$ ) and assessed on an operant fixed ratio I (FRI) sucrose pellet self-administration schedule for I 50 min. Mice were tested for a total of four consecutive sessions. (b) Total active lever presses during the task. Veh-treated mice show discrete temporal FRI responses. Glu significantly blunted FR responses at 30 and 90 min into the task. BC accentuated the inhibitory effect of glucose on FR responding. **** $P \leqslant 0.001$, *** $p \leqslant 0.01$, and *p $\leqslant 0.05$, two-way repeated measures ANOVA with Holm-Šídák post hoc tests. (c) Inactive lever presses during the task. (d) Glu significantly decreased the total number of pellets earned during each session compared with both Veh/Veh sessions. Pretreatment with BC accentuated the Glu-mediated decrease in pellets earned. *** $P \leqslant 0.01$ and $* p \leqslant 0.05, t=0.052$, two-way repeated measures ANOVA with Holm-Šídák post hoc tests. (e) Glu significantly decreased the total number of pellets consumed during each session compared with both Veh/Veh sessions. Pretreatment with BC completely abolished sucrose pellet consumption. **** $P \leqslant 0.001$ and * $p \leqslant 0.05$, two-way repeated measures ANOVA with Holm-Šídák post hoc tests. Data are shown as mean \pm SEM.

glucose-derived reinforcement learning mechanisms. We propose that NAc shell D2R-mediated glucoregulation interacts with DA-mediated food reward and reinforcement learning mechanisms to drive changes in normal feeding and appetitive drive. Although the specific mechanism by which this may occur is not currently known, a potential candidate may be a neurocircuit comprising D2R MSNs and their efferent projections to ventral pallidum (VP), followed by VP efferents to the lateral hypothalamus (LH) (Groenewegen et al, 1993), and finally direct LH efferents to the pancreas, known to modulate blood glucose levels (Rosario et al, 2016).
Future studies will focus at elucidating involvement of this circuit in blood glucose changes.

In sum, we propose that D2R-expressing NAc shell MSNs serve as a novel metabolic-cognitive brain interface integrating homeostatic glucose signaling with nutrient-derived, metabolic reinforcement learning signals to form nutrient-flavor preferences and sustained reinforcement learning. Moreover, it may be possible that D2R signaling, perhaps via the VP and LH network described above, can contribute to overriding normal learning processes in efforts of adopting appropriate behavioral strategies (ie, perseveration) for maximizing nutrient ingestion and ensuring survival during 
unique environmental situations (eg, food availability, threats, and so on). Aberrant functioning of this regulatory system, particularly in a setting where nutrient-rich food is plentiful, may lead to the potential of metabolic disturbances and maladaptive behaviors such as impulsive feeding and overeating, eventually increasing risk for obesity and/or metabolic disorders. Indeed, D2R disturbances have been reported in obese humans as well as animal obesity models (Friend et al, 2017; Kenny et al, 2013; Volkow and Baler, 2015; Volkow et al, 2013). Interestingly, a recent study reported that deletion of D2R from MSNs was associated with physical activity deficits in the context of obesity (Friend et al, 2017). Conversely, this study also showed that increased $G_{i}$ activation in striatal MSNs led to increased physical activity (Friend et al, 2017). These findings are consistent with the results described here and in fact suggest that the increased operant seeking behaviors for sucrose that we observed in $\mathrm{D} 32^{\mathrm{fl} / \mathrm{fl}} / \mathrm{D} 2 \mathrm{cre}^{+}$mice may be driven in part by increased energy requirements brought upon by increases in locomotor activity. Nevertheless, any potential effects of increased locomotor activity on operant sucrose seeking behaviors and sucrose intake would be expected to have a weaker impact than those influenced by the profound glucose metabolic impairments observed in these mice.

In addition to obesity, our above findings may also be relevant for substance abuse as D2R disturbances are widely reported in human substance abusers and animal drug abuse models (Kenny et al, 2013; Michaelides et al, 2012; Volkow and Baler, 2015; Volkow et al, 2013). Intriguingly, centrally acting D2R medications are clinically used for management of type 2 diabetes (Scranton and Cincotta, 2010), and medications that, in part, alter peripheral glucose metabolism are being proposed as novel therapeutics for drug abuse (Engel and Jerlhag, 2014). Finally, the novel behavioral and metabolic attributes of striatal D2R signaling described herein may be relevant for better understanding psychiatric-metabolic disease comorbidities as D2R-related psychiatric disorders are comorbid with obesity and metabolic dysregulation (Leonard et al, 2012; Roy and Lloyd, 2012) and D2R-selective psychiatric medications are associated with obesity and glucose abnormalities (De Hert et al, 2012).

\section{FUNDING AND DISCLOSURE}

MM is a cofounder and owns stock in Metis Laboratories. The other authors declare no conflict of interest.

\section{ACKNOWLEDGMENTS}

We thank Dr Paul Greengard for providing access to the $\mathrm{D} 32^{\mathrm{fl} / \mathrm{fl}} / \mathrm{D} 2 \mathrm{cre}^{+}$and $\mathrm{D} 32^{\mathrm{fl} / \mathrm{fl}} / \mathrm{D} 2 \mathrm{cre}^{-}$mice. This work was supported by the NIDA (DA030359 and DA033660 to YLH) and the NIDA Intramural Research Program (ZIADA000069) to MM. MM was supported by the NIDA Postdoctoral Training Program at Icahn School of Medicine at Mount Sinai (DA007135). MLM was supported by F30 (DA038954) and T32 (GM007280) grants. All co-authors reviewed the manuscript and provided comments.

\section{REFERENCES}

Ackroff K, Yiin YM, Sclafani A (2010). Post-oral infusion sites that support glucose-conditioned flavor preferences in rats. Physiol Behav 99: 402-411.

Ahmed SH, Guillem K, Vandaele Y (2013). Sugar addiction: pushing the drug-sugar analogy to the limit. Curr Opin Clin Nutr Metab Care 16: 434-439.

Bateup HS, Santini E, Shen W, Birnbaum S, Valjent E, Surmeier DJ et al (2010). Distinct subclasses of medium spiny neurons differentially regulate striatal motor behaviors. Proc Natl Acad Sci USA 107: 14845-14850.

Beeler JA, McCutcheon JE, Cao ZF, Murakami M, Alexander E, Roitman MF et al (2012). Taste uncoupled from nutrition fails to sustain the reinforcing properties of food. Eur J Neurosci 36: 2533-2546.

Bello NT, Hajnal A (2006). Alterations in blood glucose levels under hyperinsulinemia affect accumbens dopamine. Physiol Behav 88: 138-145.

Borgkvist A, Fisone G (2006). Psychoactive drugs and regulation of the cAMP/PKA/DARPP-32 cascade in striatal medium spiny neurons. Neurosci Biobehav Rev 31: 79-88.

Centonze D, Picconi B, Gubellini P, Bernardi G, Calabresi P (2001). Dopaminergic control of synaptic plasticity in the dorsal striatum. Eur J Neurosci 13: 1071-1077.

de Araujo IE (2011). Multiple Reward Layers in Food Reinforcement. In: Gottfried JA (ed). Neurobiology of Sensation and Reward. CRC Press/Taylor \& Francis: Boca Raton (FL), 2011.

de Araujo IE, Lin T, Veldhuizen MG, Small DM (2013). Metabolic regulation of brain response to food cues. Curr Biol 23: 878-883.

De Hert M, Detraux J, van Winkel R, Yu W, Correll CU (2012). Metabolic and cardiovascular adverse effects associated with antipsychotic drugs. Nat Rev Endocrinol 8: 114-126.

de Leeuw van Weenen JE, Parlevliet ET, Maechler P, Havekes LM, Romijn JA, Ouwens DM et al (2010). The dopamine receptor D2 agonist bromocriptine inhibits glucose-stimulated insulin secretion by direct activation of the alpha2-adrenergic receptors in beta cells. Biochem Pharmacol 79: 1827-1836.

Delaere F, Akaoka H, De Vadder F, Duchampt A, Mithieux G (2013). Portal glucose influences the sensory, cortical and reward systems in rats. Eur J Neurosci 38: 3476-3486.

Diepenbroek C, Rijnsburger M, Eggels L, van Megen KM, Ackermans MT, Fliers E et al (2016). Infusion of fluoxetine, a serotonin reuptake inhibitor, in the shell region of the nucleus accumbens increases blood glucose concentrations in rats. Neurosci Lett 637: 85-90.

Diepenbroek C, van der Plasse G, Eggels L, Rijnsburger M, Feenstra MG, Kalsbeek A et al (2013). Alterations in blood glucose and plasma glucagon concentrations during deep brain stimulation in the shell region of the nucleus accumbens in rats. Front Neurosci 7: 226.

Engel JA, Jerlhag E (2014). Role of appetite-regulating peptides in the pathophysiology of addiction: implications for pharmacotherapy. CNS Drugs 28: 875-886.

Fienberg AA, Hiroi N, Mermelstein PG, Song W, Snyder GL, Nishi A et al (1998). DARPP-32: regulator of the efficacy of dopaminergic neurotransmission. Science (New York, NY) 281: 838-842.

Friend DM, Devarakonda K, O'Neal TJ, Skirzewski M, Papazoglou I, Kaplan AR et al (2017). Basal ganglia dysfunction contributes to physical inactivity in obesity. Cell Metabol 25: 312-321.

Garcia-Tornadu I, Ornstein AM, Chamson-Reig A, Wheeler MB, Hill DJ, Arany E et al (2010). Disruption of the dopamine d2 receptor impairs insulin secretion and causes glucose intolerance. Endocrinology 151: 1441-1450.

Green L, Estle SJ (2003). Preference reversals with food and water reinforcers in rats. J Exp Anal Behav 79: 233-242. 
Groenewegen HJ, Berendse HW, Haber SN (1993). Organization of the output of the ventral striatopallidal system in the rat: ventral pallidal efferents. Neuroscience 57: 113-142.

Halpern CH, Tekriwal A, Santollo J, Keating JG, Wolf JA, Daniels D et al (2013). Amelioration of binge eating by nucleus accumbens shell deep brain stimulation in mice involves D2 receptor modulation. J Neurosci 33: 7122-7129.

Haluk DM, Floresco SB (2009). Ventral striatal dopamine modulation of different forms of behavioral flexibility. Neuropsychopharmacology 34: 2041-2052.

Horvitz JC, Williams G, Joy R (2001). Time-dependent actions of D2 family agonist quinpirole on spontaneous behavior in the rat: dissociation between sniffing and locomotion. Psychopharmacology (Berl) 154: 350-355.

Johnson RK, Appel LJ, Brands M, Howard BV, Lefevre M, Lustig RH et al (2009). Dietary sugars intake and cardiovascular health: a scientific statement from the American Heart Association. Circulation 120: 1011-1020.

Kenny PJ, Voren G, Johnson PM (2013). Dopamine D2 receptors and striatopallidal transmission in addiction and obesity. Curr Opin Neurobiol 23: 535-538.

Kravitz AV, Kreitzer AC (2012). Striatal mechanisms underlying movement, reinforcement, and punishment. Physiology (Bethesda) 27: 167-177.

Kruzich PJ, Mitchell SH, Younkin A, Grandy DK (2006). Dopamine D2 receptors mediate reversal learning in male C57BL/6J mice. Cogn Affect Behav Neurosci 6: 86-90.

Laitinen JT, Jokinen M (1998). Guanosine 5'-(gamma-[35S]thio) triphosphate autoradiography allows selective detection of histamine $\mathrm{H} 3$ receptor-dependent $\mathrm{G}$ protein activation in rat brain tissue sections. $J$ Neurochem 71: 808-816.

Lennerz BS, Alsop DC, Holsen LM, Stern E, Rojas R, Ebbeling CB et al (2013). Effects of dietary glycemic index on brain regions related to reward and craving in men. Am J Clin Nutr 98: 641-647.

Leonard BE, Schwarz M, Myint AM (2012). The metabolic syndrome in schizophrenia: is inflammation a contributing cause? J Psychopharmacol 26(Suppl 5): 33-41.

Lindskog M (2008). Modelling of DARPP-32 regulation to understand intracellular signaling in psychiatric disease. Pharmacopsychiatry 41(Suppl 1): S99-s104.

Lindskog M, Svenningsson P, Fredholm BB, Greengard P, Fisone G (1999). Activation of dopamine D2 receptors decreases DARPP-32 phosphorylation in striatonigral and striatopallidal projection neurons via different mechanisms. Neuroscience $\mathbf{8 8}$ : 1005-1008.

Lobo MK, Nestler EJ (2011). The striatal balancing act in drug addiction: distinct roles of direct and indirect pathway medium spiny neurons. Front Neuroanat 5: 41.

Mark GP, Smith SE, Rada PV, Hoebel BG (1994). An appetitively conditioned taste elicits a preferential increase in mesolimbic dopamine release. Pharmacol Biochem Behav 48: 651-660.

Michaelides M, Thanos PK, Volkow ND, Wang GJ (2012). Translational neuroimaging in drug addiction and obesity. ILAR J 53: 59-68.

Moreno M, Economidou D, Mar AC, Lopez-Granero C, Caprioli D, Theobald DE et al (2013). Divergent effects of D(2)/(3) receptor activation in the nucleus accumbens core and shell on impulsivity and locomotor activity in high and low impulsive rats. Psychopharmacology (Berl) 228: 19-30.

Nishi A, Snyder GL, Greengard P (1997). Bidirectional regulation of DARPP-32 phosphorylation by dopamine. J Neurosci 17: 8147-8155.

Oliveira-Maia AJ, Roberts CD, Walker QD, Luo B, Kuhn C, Simon SA et al (2011). Intravascular food reward. PLoS ONE 6: e24992.

Page KA, Chan O, Arora J, Belfort-Deaguiar R, Dzuira J, Roehmholdt B et al (2013). Effects of fructose vs glucose on regional cerebral blood flow in brain regions involved with appetite and reward pathways. JAMA 309: 63-70.

Pizzolato G, Soncrant TT, Rapoport SI (1985). Time-course and regional distribution of the metabolic effects of bromocriptine in the rat brain. Brain Res 341: 303-312.

Rosario W, Singh I, Wautlet A, Patterson C, Flak J, Becker TC et al (2016). The brain-to-pancreatic islet neuronal map reveals differential glucose regulation from distinct hypothalamic regions. Diabetes 65: 2711-2723.

Roy T, Lloyd CE (2012). Epidemiology of depression and diabetes: a systematic review. J Affect Disord 142(Suppl): S8-21.

Saller CF, Kreamer LD (1991). Glucose concentrations in brain and blood: regulation by dopamine receptor subtypes. Brain Res 546: 235-240.

Scheggi S, Secci ME, Marchese G, De Montis MG, Gambarana C (2013). Influence of palatability on motivation to operate for caloric and non-caloric food in non food-deprived and food-deprived rats. Neuroscience 236: 320-331.

Schmidt MJ, Root MA, Hall JL (1983). Dopamine agonist-induced hyperglycemia in rats: structure-activity relationships and mechanisms of action. Eur J Pharmacol 90: 169-177.

Schulte EM, Avena NM, Gearhardt AN (2015). Which foods may be addictive? The roles of processing, fat content, and glycemic load. PLoS ONE 10: e0117959.

Sclafani A, Ackroff K (2012). Flavor preferences conditioned by intragastric glucose but not fructose or galactose in C57BL/ 6J mice. Physiol Behav 106: 457-461.

Sclafani A, Cardieri C, Tucker K, Blusk D, Ackroff K (1993). Intragastric glucose but not fructose conditions robust flavor preferences in rats. Am J Physiol 265(2 Pt 2): R320-R325.

Scranton R, Cincotta A (2010). Bromocriptine-unique formulation of a dopamine agonist for the treatment of type 2 diabetes. Expert Opin Pharmacother 11: 269-279.

Trifilieff P, Feng B, Urizar E, Winiger V, Ward RD, Taylor KM et al (2013). Increasing dopamine D2 receptor expression in the adult nucleus accumbens enhances motivation. Mol Psychiatry 18: 1025-1033.

Tsurugizawa T, Kondoh T, Torii K (2008). Forebrain activation induced by postoral nutritive substances in rats. Neuroreport 19: 1111-1115.

Volkow ND, Baler RD (2015). NOW vs LATER brain circuits: implications for obesity and addiction. Trends Neurosci 38: 345-352.

Volkow ND, Wang GJ, Tomasi D, Baler RD (2013). The addictive dimensionality of obesity. Biol Psychiatry 73: 811-818.

Yawata S, Yamaguchi T, Danjo T, Hikida T, Nakanishi S (2012). Pathway-specific control of reward learning and its flexibility via selective dopamine receptors in the nucleus accumbens. Proc Natl Acad Sci USA 109: 12764-12769. 